\title{
Geophysical borehole logging for control of driller's records: hydrogeological case study from Voltaian sedimentary rocks in northern Ghana
}

\author{
William Agyekum • Kurt Klitten • Thomas Armah • \\ Bruce Banoeng-Yakubo $\cdot$ Edmund Okoe Amartey
}

Received: 27 September 2012/ Accepted: 18 March 2013/Published online: 4 April 2013

(C) The Author(s) 2013. This article is published with open access at Springerlink.com

\begin{abstract}
The low borehole yielding potential and the high drilling failure rate of the Voltaian sedimentary rocks of Northern Ghana have been of concern to many local hydrogeologists and international donors. Consequently, several donor-supported projects have been instituted within the last few years with the view to study the hydrogeological characteristics of this 'difficult' rock system. One such project is the geophysical borehole logging of 13 boreholes drilled into the Voltaian sedimentary rocks of Northern Ghana to enhance detailed hydrogeological assessment. Natural gamma detectors embedded in the five exploratory logging tools employed for the study ensured depth control by comparing their individual gamma log signatures. The combined gamma and formation resistivity/ conductivity response logs provided more detailed lithological information than were shown in the driller's/geologist's logs. Significant discrepancies between the logging results and the reported drilled depths, construction depths, and screen settings were observed in seven of the thirteen investigated boreholes. Thus, the reliability of driller's borehole records seems questionable, which will hamper hydrogeological studies and the mapping of groundwater resources. Further, it may be supposed that the productivity
\end{abstract}

W. Agyekum

CSIR Water Research Institute (WRI), Accra, Ghana

K. Klitten

Geocenter, Øster Voldgade 10, 1350 Copenhagen K, Denmark

T. Armah · B. Banoeng-Yakubo

Geology Department, University of Ghana, Legon, Accra, Ghana

E. O. Amartey $(\bowtie)$

Ghana Atomic Energy Commission, Accra, Ghana

e-mail: edalaska2000@yahoo.com of most wells in Ghana is compromised by poor depth control of screen placement.

Keywords Groundwater - Borehole logging · Driller's records $\cdot$ Reliability $\cdot$ Voltaian rocks $\cdot$ Ghana

\section{Introduction}

Many hydrogeologists and groundwater experts have raised serious concerns about the low drilling success rate and the poor borehole yielding potential of the Paleozoic sedimentary rock system of Northern Ghana (Martin and van de Giesen 2005). With the view to understand the hydrogeological framework and to strengthen the current knowledge base of the underlying low-yielding and 'difficult' rock system, several donor groundwater projects, including DANIDA-funded groundwater monitoring project of the White Volta River Basin within Northern Ghana and CIDA-funded Hydrogeological Assessment Project (HAP) of Northern Ghana were carried out between 2006 and 2010. The CIDA-funded HAP project in particular intended to provide comprehensive hydrogeological overview of the sedimentary rock system, which underlies the study area. As part of the project implementation, 22 exploratory boreholes were drilled, out of which 13 were located within the Paleozoic sedimentary rock system whereas the remaining 9 were located within Precambrian crystalline basement rocks.

Location and physical setting

The study area encompasses the three northern regions of Ghana (Upper East, Upper West and Northern regions), and falls within the boundaries of latitudes $8^{\circ} 10^{\prime}-11^{\circ} \mathrm{N}$ 
and longitudes $0.5^{\circ} \mathrm{E}-2^{\circ} 30^{\prime} \mathrm{W}$ (Fig. 1). It covers an approximate area of $97,700 \mathrm{~km}^{2}$ and represents nearly $41 \%$ of the landmass of Ghana with $35 \%$ of the country's population inhabiting in it (Ghana Statistical Service 2005). The area falls within semi-arid climatic region with variable rainfall intensity. Annual rainfall values are low, seasonal and erratic, and range considerably from month to month with mean annual values ranging from $1,140 \mathrm{~mm}$ in the south to $927 \mathrm{~mm}$ in the north (Nathan 1970).

Geology and hydrogeology

About $55 \%$ of the geology of northern Ghana is made up of consolidated Paleozoic sedimentary rocks which have been locally referred to as Voltaian sedimentary rocks by Junner and Hirst (1946). The remaining $45 \%$ comprises Granitic and Birimian formations with some isolated patches of Tarkwaian, Togo and Buem rock types, all belonging to the Precambrian crystalline basement complex formation (Fig. 2).

The Voltaian sedimentary rocks are generally wellconsolidated and gently folded, and comprise sandstone, shale, mudstone, sandy and pebbly beds and limestone. On the basis of remote sensing, image interpretation and field mapping, the chronostratigraphy of the Voltaian system has recently been revised by Affaton (2008), Carney et al. (2008) and Jordan et al. (2008) by subdividing the Voltaian into four (4) main lithostratigraphic units: Tossiegou,
Fig. 1 Map of Ghana showing the location of the Study Area

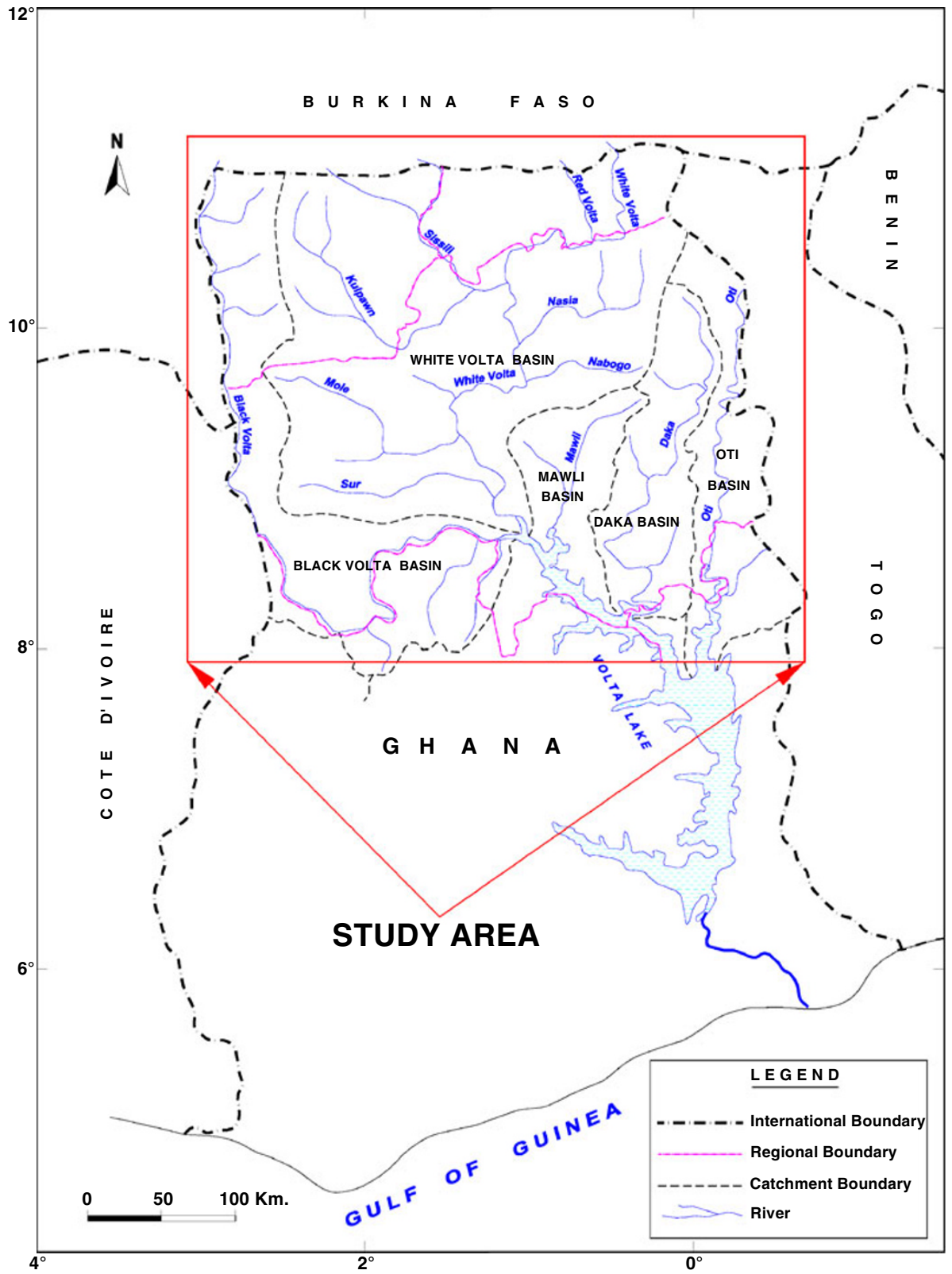




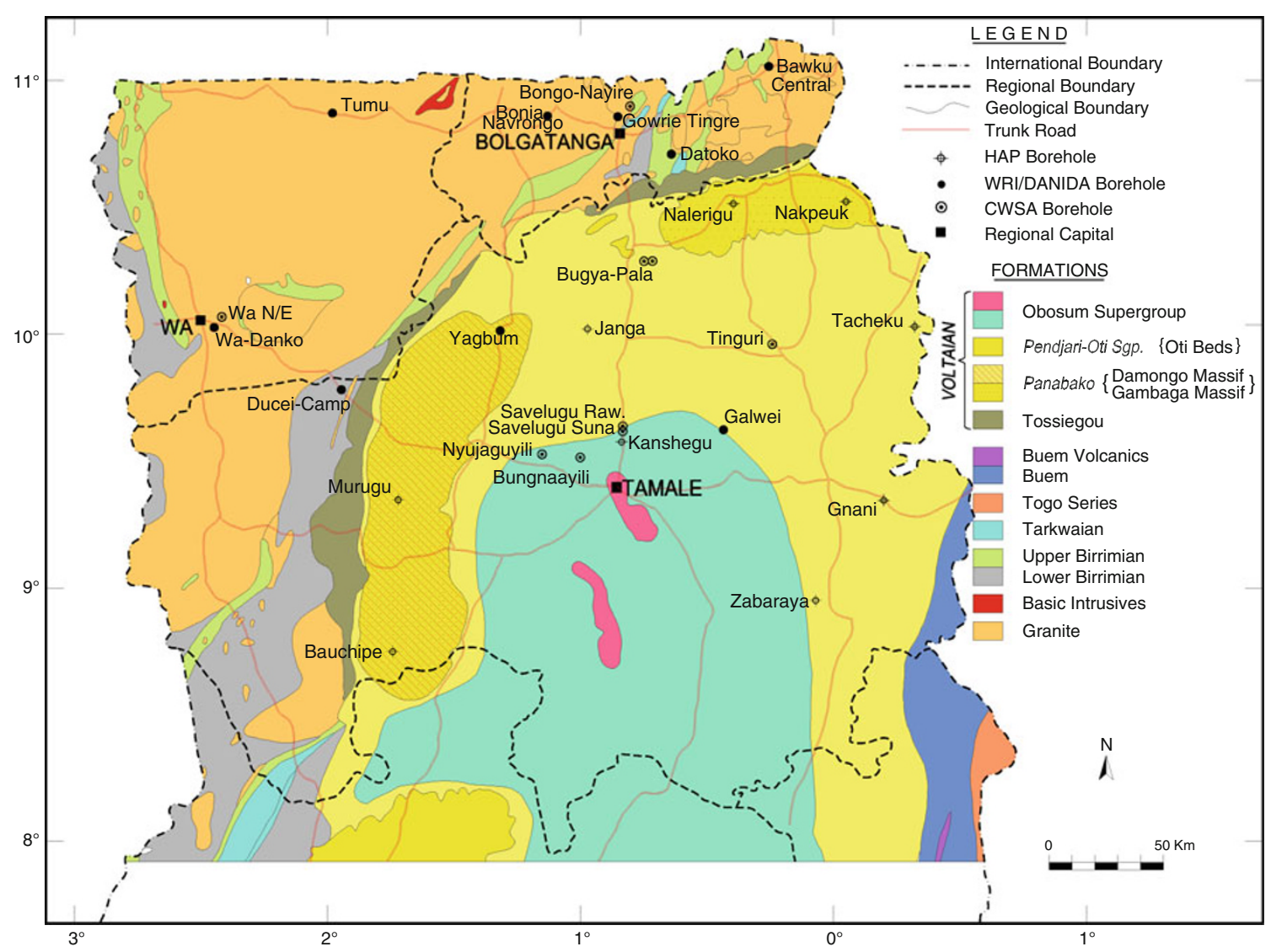

Fig. 2 Geological map of the Study Area showing location of the study boreholes

Panabako, Pendjari Oti, and Obosum Supergroups (Fig. 2), and suggesting the Obosum Supergroup as the youngest and Tossiegou as the oldest.

The Panabako supergroup comprises quartzitic sandstone and siltstone, and forms the higher ground bordering the southern, western and northern fringes of the Voltaian basin. Based upon lithological differences and mineralogical content, Jordan et al. (2008) further subdivided the Panabako formation into Damongo massif (Bauchipe, Murugu, and Yagbum boreholes on Fig. 2) and Gambaga massif (Nalerigu and Nakpeuk boreholes on Fig. 2). Whereas the Damongo massif comprises fine to coarsegrained feldspathic, massive and thin-bedded quartzitic and well-consolidated sandstone, the Gambaga massif comprises prodelta mudstones and siltstones, grading gradually to nearshore facies and quartz arenites (Jordan et al. 2008).

Referred previously by Junner and Hirst (1946) as Middle Voltaian Obosum and Oti beds, Jordan et al. (2008) renamed these rock units as Pendjari Oti and Obosum Supergroup. The Pendjari Oti comprises well-consolidated and closely compacted and impermeable rocks, whilst the Obosum group largely comprises variegated mudstone, clays, and siltstone interbedded with micaceous sandstone and interbedded conglomerates (Bates 1966).
Many hydrogeologists such as Gills (1969), Frempong and Kortatsi (1994), MacDonald et al. (1996), DapaahSiakwan and Gyau-Boakye (2000), Acheampong and Hess (2000) and Agyekum and Dapaah-Siakwan (2007) have reported about the generally poor yielding potential of the Voltaian rocks, though varying widely from 0.3 to $72 \mathrm{~m}^{3} / \mathrm{hr}(5-1,200 \mathrm{lpm})$ with the higher yields recorded in areas underlain by quartzitic sandstone rocks. Lower potentials on the other hand have been recorded in the clayrich Obosum shale and mudstone environment as also described by Darko and Krasny (2007). Darko (2001) further described the hydraulic characteristics of the Voltaian sedimentary environment as heterogeneous with intermediate to low transmissivity values that range widely between 0.3 and $267 \mathrm{~m}^{2} / \mathrm{d}$.

\section{Data and investigation methods}

Driller's and geologist's log

During the drilling of the 22 donor-funded exploratory boreholes, a geologist from the Ghana Geological Survey Department (GSD) was attached to the drilling crew to 
provide accurate and detailed geological and structural description of all soils and rocks penetrated. Geophysical borehole logging was conducted on all 22 boreholes several months after drilling and construction was completed. Prior to running the logs, the drilling records on soil/rocks penetrated, drilled depth and construction details (including screen setting depths) of the boreholes were collected from both the supervising geologist and the drilling contractor. The driller's information on drilling depth is normally based upon the log tally of the drill rods during drilling. Six of the thirteen boreholes were open constructed, whilst the remaining seven were fully constructed with PVC screens and gravel pack. Drilling and logging information about the 13 boreholes are provided in Table 1, and their location is shown on Fig. 2 together with the remaining nine boreholes drilled outside the Voltaian basin. Location of some few old Community Water and Sanitation Agency (CWSA) boreholes is also shown. Even though logging was conducted on these boreholes, their results are not included in this paper due to lack of driller's borehole records.

\section{Geophysical borehole logging}

Pumping test was conducted on each borehole prior to logging to obtain information on their aquifer characteristics as well as their maximum allowable drawdown. The accessible depth section of each borehole was logged every $1 \mathrm{~cm}$ interval, using a set of five digital geologging tools (probes), Robertson's (RG) Micrologger, Winch, and a Computer. The probes are made of noncorroding materials and are designed to withstand high water pressures. They enclose sensors, signal transmitters, receivers, and power supplies. The Micrologger is the main data collection and storage unit and consists of large capacity memory unit for data storage. The Winch is made up of lightweight portable cable drum on which a $400 \mathrm{~m}$ long 1/10-inch monocable is wound. For field setup, the Micrologger is connected to three cables that link the computer, power supply, and the Winch. Another cable also links the Winch to a depth encoder on a tripod, and this is finally connected to a cable head that carries the logging tool into the target borehole. The basic configuration and field setup is presented in Fig. 3.

To ensure the accuracy of the sub-surface data to be generated, each probe was calibrated prior to embarking on the data collection. Furthermore, the internal calibration function facility for each tool of the digital logging device was utilized prior to running the logs. In addition, the depth encoder used for the data collection provided depth control with an accuracy of $10 \mathrm{~cm}$ per every $100 \mathrm{~m}$ logged depth. The logging tools used were:

1. 3-Arm Caliper (3-ACS) in open-constructed boreholes for obtaining information on the borehole diameter, as well as identifying weak and fissure zones. The 3-ACS tool comprised three arms of standard length of $38 \mathrm{~mm}$ each, which were mechanically coupled to the logging tool. To run this $\log$, the caliper tool was lowered to the bottom of the borehole with the arms retracted. At the bottom of the borehole, the arms were made to open to begin the logging in the upward direction, where the spring-loaded arms open to respond to variations in the borehole diameter.

Table 1 Borehole records and geologging probes used in each well, and Swl at logging date

\begin{tabular}{|c|c|c|c|c|c|c|c|c|c|c|}
\hline \multirow[t]{2}{*}{ Well } & \multirow[t]{2}{*}{ Id no. } & \multirow[t]{2}{*}{ Date drilled } & \multirow[t]{2}{*}{ Date logged } & \multirow[t]{2}{*}{ Status } & \multirow{2}{*}{$\begin{array}{l}\text { Swl during } \\
\log \text { run }(\mathrm{m})\end{array}$} & \multicolumn{5}{|c|}{ Logging tools used } \\
\hline & & & & & & $3 \mathrm{ACS}$ & GLOG & TCGS & DUIN & HRFM \\
\hline Murugu & HAP1 & Aug, 2006 & July, 2007 & Pvc cased & 28.64 & $-{ }^{\mathrm{a}}$ & - & $\mathrm{X}^{\mathrm{b}}$ & $\mathrm{X}$ & $\mathrm{X}$ \\
\hline Bauchipe & HAP2 & Aug, 2006 & Aug, 2007 & Open & 48.28 & $\mathrm{X}$ & $\mathrm{X}$ & $\mathrm{X}$ & $\mathrm{X}$ & - \\
\hline Kanshegu & HAP4 & Aug. 2006 & Sept, 2007 & Pvc cased & 9.65 & - & - & $\mathrm{X}$ & $\mathrm{X}$ & $\mathrm{X}$ \\
\hline Janga & HAP5 & Aug; 2006 & Sept, 2007 & Pvc cased & 7.36 & $\mathrm{X}$ & $\mathrm{X}$ & $\mathrm{X}$ & $\mathrm{X}$ & - \\
\hline Zabaraya & HAP7 & Aug, 2006 & Aug, 2007 & Pvc cased & 5.43 & - & - & $\mathrm{X}$ & $\mathrm{X}$ & $\mathrm{X}$ \\
\hline Gnani & HAP8 & Aug, 2006 & Aug, 2007 & Open & 25.18 & - & - & $\mathrm{X}$ & $\mathrm{X}$ & $\mathrm{X}$ \\
\hline Tachecku & HAP10 & Sept, 2006 & Aug, 2007 & Open & 1.63 & $\mathrm{X}$ & - & $X$ & $\mathrm{X}$ & $X$ \\
\hline Nalerigu & HAP11 & Sept, 2006 & Sept, 2007 & Pvc cased & 5.3 & - & - & $\mathrm{X}$ & $\mathrm{X}$ & $\mathrm{X}$ \\
\hline Nakpeuk & HAP12 & Sept, 2006 & Aug, 2007 & Open & 5.25 & $\mathrm{X}$ & $\mathrm{X}$ & - & $\mathrm{X}$ & $\mathrm{X}$ \\
\hline Yagbum & WVB10 & June, 2005 & March 2007 & Open & 20.58 & $X$ & $\mathrm{X}$ & - & $\mathrm{X}$ & $X$ \\
\hline Bugya-Pala & WVB11 & April, 2003 & Oct, 2006 & Open & 6.77 & $X$ & $\mathrm{X}$ & - & - & $\mathrm{X}$ \\
\hline Tinguri & WVB12 & March, 2002 & March 2007 & Pvc cased & 9.15 & - & - & $X$ & $\mathrm{X}$ & $\mathrm{X}$ \\
\hline Galiwei & WVB13 & June, 2005 & July, 2007 & Open & 32.32 & $X$ & - & - & $\mathrm{X}$ & - \\
\hline
\end{tabular}

$s w l$ static water level

a $\mathrm{X}$ means logging probe used on borehole

b -means probe not used on borehole 
Fig. 3 Basic configuration of the field geologging setup

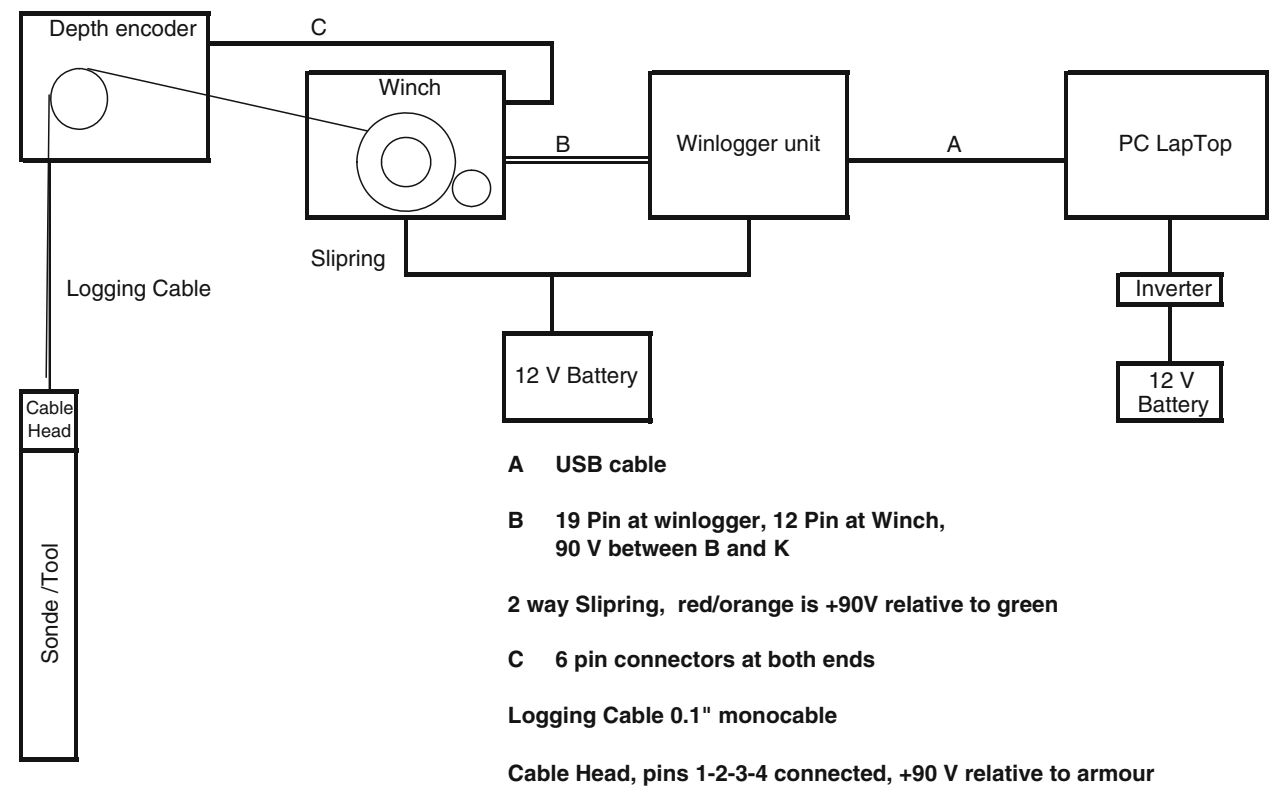

2. Focussed Guard (GLOG) tool was used to obtain information about the formation resistivity within the close vicinity of each open-constructed borehole. Furthermore, the GLOG tool was used in fully constructed boreholes, but then aiming to identify the placement depth and length of screens.

3. Dual Induction (DUIN) tool was run only in fully constructed boreholes and aiming to obtain information on formation conductivity, which could be $\log$ transformed into formation resistivity through pvc casings where the GLOG tool does not provide valid data. The data obtained from each of these two logging probes combined with the gamma ray response values were used to enhance lithological interpretation of the rocks penetrated (Freeze and Cherry 1979).

4. In addition, Fluid Temperature and Conductivity (TCGS) logging tool conducted under static water condition was used to determine the log profile of groundwater salinity and temperature. It was further applied to identify inflow zones by conducting this log also during pumping water from the borehole, thus complementing the flowmeter log (see below).

5. Finally, High Resolution Impeller flowmeter (HRFM) logging tool was employed to determine inflow distribution, which could be expressed as the percentage water contribution from each inflow zone to the total flow volume of each borehole. Logging under pumping conditions entailed that the TCGS as well as the HRFM logging tool was suspended below the suction head of the pump and logging conducted from close to the pump in the downward direction. Table 1 presents some basic information about the logged boreholes and the logging probes used on each of them.

\section{Results and discussions}

Owing to the large volume of the logging data generated by each logging tool, they were resampled from 1 to $5 \mathrm{~cm}$ sample intensity by averaging every five data values. The data generated were collated and processed using Viewlog software (Kettelar 2005) and displayed in a standard composite $\log$ format. The composite logs were further corrected, replotted, filtered, and smoothened where necessary. As a means of depth control, depth correction was made by comparing and shifting to align gamma logs from two or more logging tools containing gamma ray detectors. The analyses and interpretation of the logging data in terms of drilled depths, construction details and profiles of soils/ rocks penetrated were compared with records obtained from the supervising geologist/driller to check for similarities and discrepancies. The comparison revealed varying degrees of discrepancies particularly with regards to drilling depths, rock description, and construction details (open and cased sections, and screen placement depths).

\section{Discrepancy in drilling depths}

The reported total drilling depth of a borehole can only be verified in an open borehole, thus before the borehole is constructed fully with pipes and screen. The reason is that it seems very unusual to install screen at the bottom of the borehole either because of blockage or because the lowermost section of the borehole has not shown any additional water inflow. This is illustrated on Fig. 4, where the total drilled depth of the borehole was reported to be $120 \mathrm{~m}$, but with construction depth of $103 \mathrm{~m}$ only, and the lowermost screen setting claimed to be from 88 to $100 \mathrm{~m}$. 
Accordingly, the drilling depth of only the six openconstructed boreholes could be verified. Fig. 5 shows the plots of the reported drilled depth, the constructed depths and those verified by geophysical borehole logging. In four of the six open-constructed boreholes are the drilling depths closely verified with marginal difference $(<3 \mathrm{~m})$ between the geophysical logging depth and reported depths, whilst in the remaining two the depths to which logging was possible were noted to be significantly shallower, with a difference of $20 \mathrm{~m}$ at Nakpeuk and $43 \mathrm{~m}$ at Janga. Such discrepancies related to drilled depths may be due to accumulation of silt/clay at the bottom of the borehole or blockage before logging.

\section{Discrepancy in construction}

Figure 4 also illustrates a discrepancy between the reported construction of the borehole and the actual construction verified by logging. The borehole was reported by the driller to be fully constructed with three screens at positions 9-12, 36-48, and 88-100 m. However, the results from resistivity (GLOG) logging (column 5) revealed that the borehole was constructed with only two screened sections, the upper one between 28 and $40 \mathrm{~m}$, and the lower one at $79-91 \mathrm{~m}$, and the bottom was reached with the
TCGS log tool at $92 \mathrm{~m}$. Such constructional discrepancy could be unintentional on the part of the driller by being inaccurate with counting the number of pipes installed and their actual length.

Figure 6 shows a similar case of discrepancy in actual construction as verified by logging and the driller's recorded screen settings of a fully constructed borehole. As a typical insulator, plain PVC is highly resistant to current flow (Keys Scott 1997). Consequently, the logged resistivity values through plain PVC pipes (column 6) are extremely high (maximum measuring range for the GLOG probe is $13,000 \Omega \mathrm{m}$ ). On the contrary, since the focussing coils of the resistivity logging (GLOG) tool is able to penetrate into the soil/rock through the slotted screens (Keys Scott 1997), the recorded formation resistivity through screened PVC pipes is much lower with values in the order of $100 \Omega \mathrm{m}$ (column 6). Consequently, it may be seen that the driller's screen setting depths of 12-21, 62-72, and 108-114 $\mathrm{m}$ were incorrect, but the correct construction profile as presented under 'interpreted log' on the right hand side of column 5 (Fig. 6) shows two screen positions only, and at the depths 10-19 and 63-108 m.

Similar wrongful screen placements and construction depths compared to the reported ones were detected in five

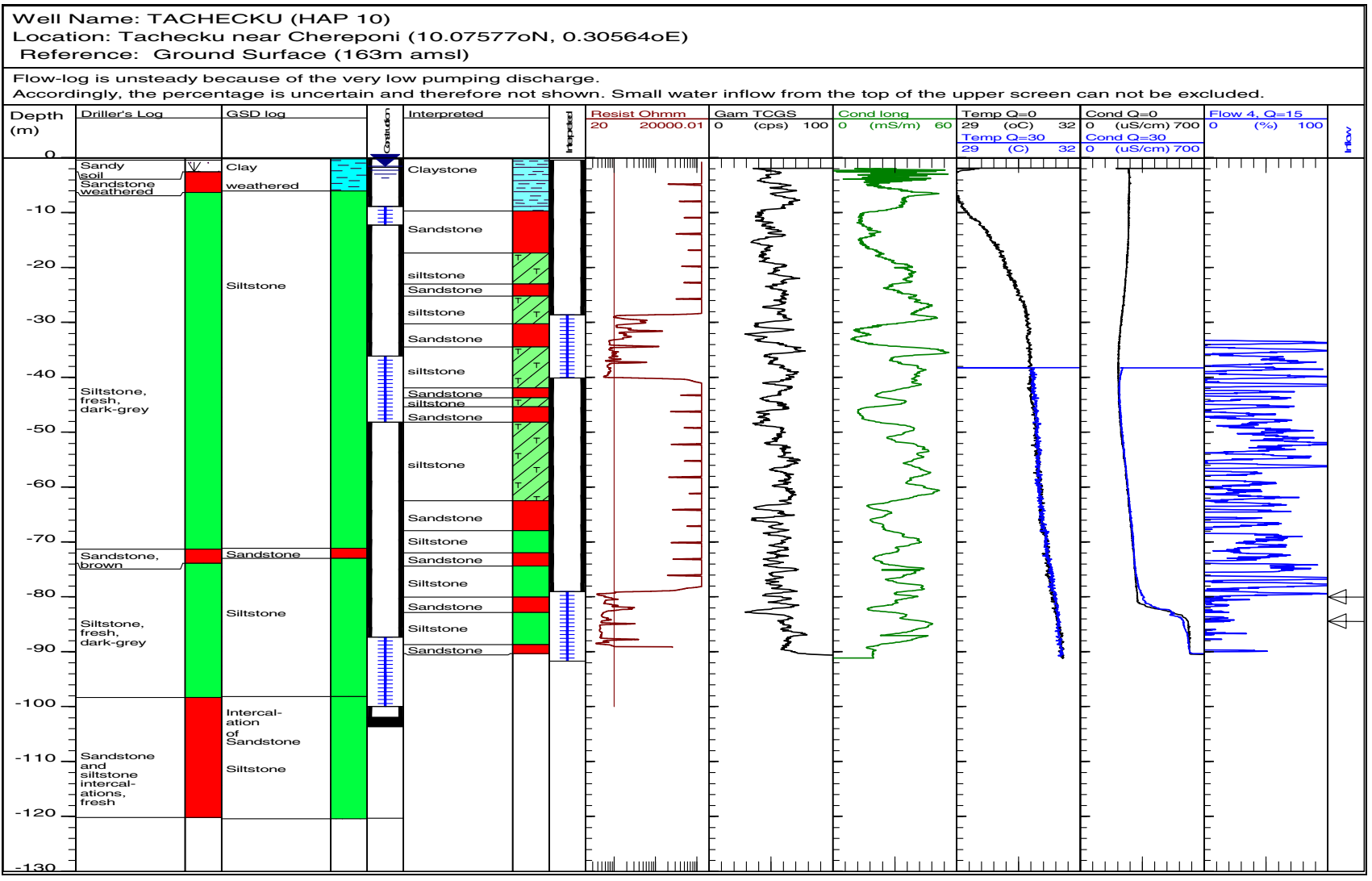

Fig. 4 Construction depth less than claimed drilled depth, and discrepancy in construction details 
Fig. 5 Driller's reported total and construction depth compared to logging depth of the boreholes
Recorded and verified depth

*6 open boreholes, 7 fully-constructed boreholes

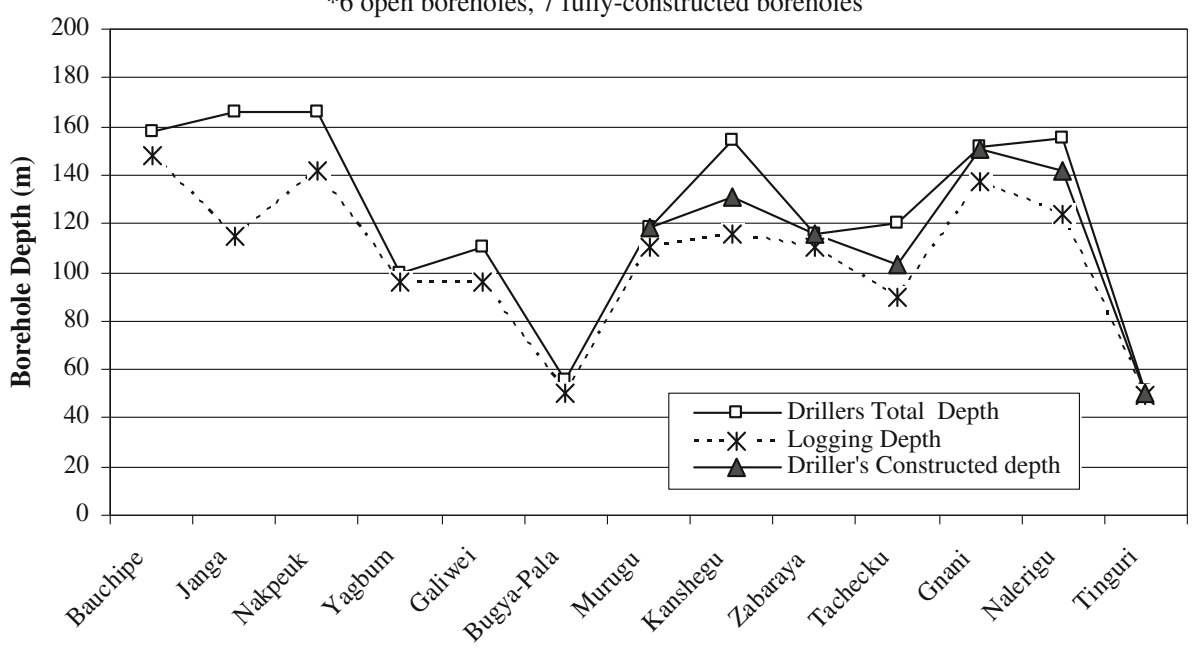

Borehole Locations of the seven fully constructed boreholes (refer to Table 2). Even though the planned screen settings may be hindered due to problems (blockage or silting) with getting the construction pipes down to the scheduled depth, it does not excuse the driller from not reporting the actual construction details. Table 2 presents the summary results from the 13 boreholes showing varying levels of discrepancies between the driller's records and geophysical log verification with respect to their cased and open sections, screen placement depths and borehole depths.

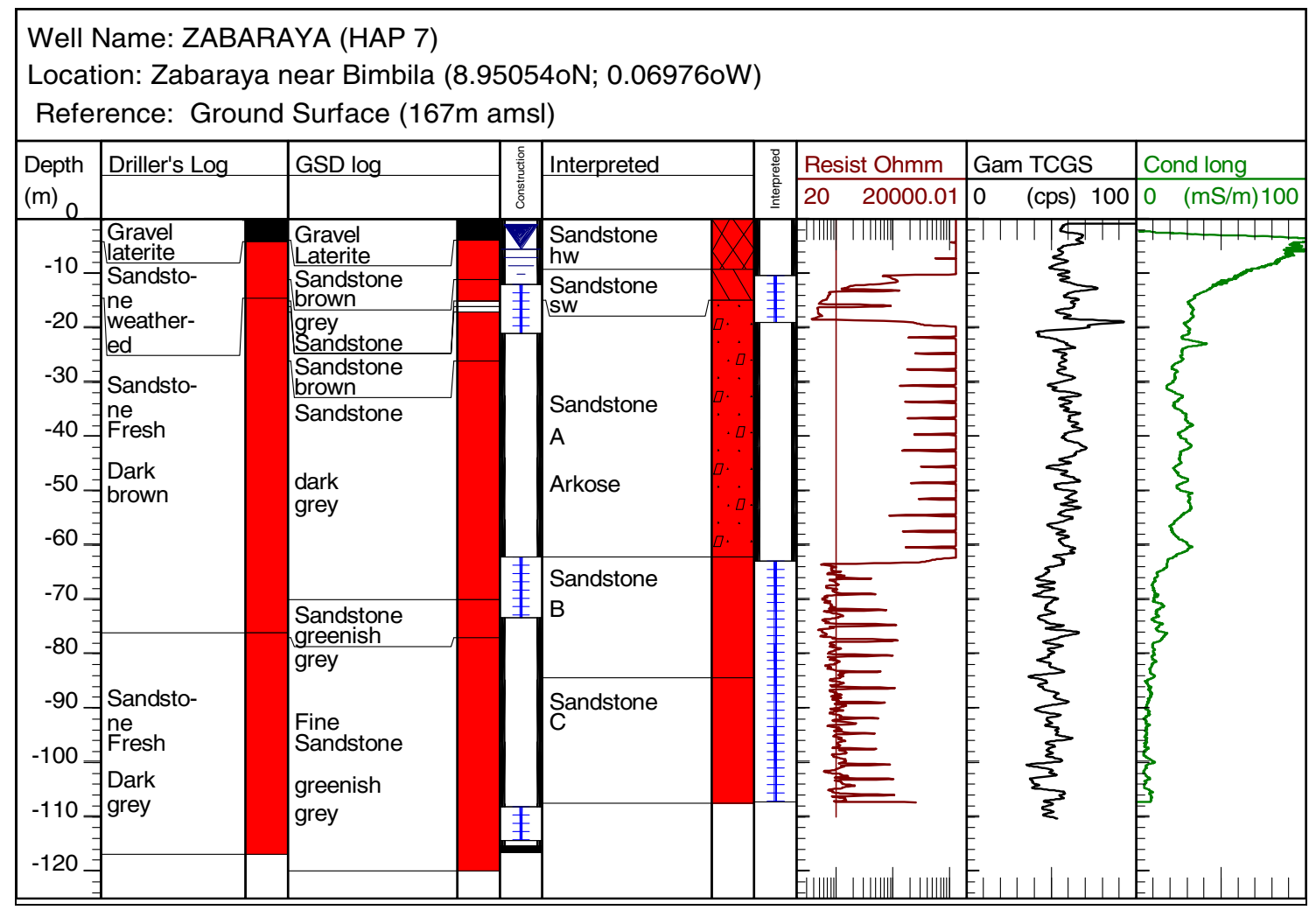

Fig. 6 Detected discrepancy in screen setting 
Table 2 Detected discrepancies between driller's log and geophysical log verification

\begin{tabular}{|c|c|c|c|c|c|c|c|c|c|}
\hline \multirow{2}{*}{$\begin{array}{l}\text { Well location } \\
\text { (id no.) }\end{array}$} & \multirow{2}{*}{$\begin{array}{l}\text { Geology } \\
\text { (Voltaian group) }\end{array}$} & \multicolumn{4}{|l|}{ Driller's log } & \multicolumn{4}{|c|}{ Geophysical log verification } \\
\hline & & $\begin{array}{l}\text { Cased } \\
\text { sections (m) }\end{array}$ & $\begin{array}{l}\text { Open } \\
\text { section (m) }\end{array}$ & $\begin{array}{l}\text { Screen } \\
\text { section (m) }\end{array}$ & $\begin{array}{l}\text { B/h depth } \\
\text { (m) }\end{array}$ & $\begin{array}{l}\text { Cased } \\
\text { sections (m) }\end{array}$ & $\begin{array}{l}\text { Open } \\
\text { section (m) }\end{array}$ & $\begin{array}{l}\text { Screen } \\
\text { section (m) }\end{array}$ & $\begin{array}{l}\text { B/h depth } \\
\text { (m) }\end{array}$ \\
\hline Murugu (HAP1) & $\begin{array}{l}\text { Panabako } \\
\text { Damongo }\end{array}$ & $0-42$ & - & $42-110$ & 118 & $0-45$ & - & $45-108$ & 110 \\
\hline $\begin{array}{l}\text { Bauchipe } \\
* \text { (HAP2) }\end{array}$ & $\begin{array}{l}\text { Panabako } \\
\text { Damango }\end{array}$ & 0-2 & $2-58$ & - & 158 & $\mathbf{0}$ & 156 & - & 156 \\
\hline Kanshegu & Obosum & $0-36$ & & $36-48$ & & $0-28$ & & $28-38$ & \\
\hline (HAP4) & & $\begin{array}{l}48-60 \\
78-110\end{array}$ & - & $\begin{array}{l}60-78 \\
110-130\end{array}$ & 155 & $\begin{array}{l}38-50 \\
68-100\end{array}$ & - & $\begin{array}{l}50-68 \\
100-117\end{array}$ & 118 \\
\hline *Janga (HAP5) & Pendjari Oti & $0-20$ & $20-166$ & - & 166 & $0-19$ & $19-123$ & - & 123 \\
\hline Zabaraya & Pendjari Oti & $0-12$ & & $12-21$ & & $0-10$ & & $10-19$ & \\
\hline (HAP7) & & $\begin{array}{l}21-62 \\
72-108\end{array}$ & - & $\begin{array}{l}62-72 \\
108-114\end{array}$ & 116 & $19-63$ & - & $63-108$ & 110 \\
\hline Gnani (HAP8) & Pendjari Oti & $0-54$ & & $54-68$ & & $0-52$ & & $52-65$ & \\
\hline & & $\begin{array}{l}68-80 \\
92-140\end{array}$ & - & $\begin{array}{l}80-92 \\
140-150\end{array}$ & 151 & $\begin{array}{l}65-76 \\
88-129\end{array}$ & - & $\begin{array}{l}\text { 76-88 } \\
129-137\end{array}$ & 138 \\
\hline Tachecku & Pendjari Oti & 0-9 & & 9-12 & & & & & \\
\hline (HAP10) & & $\begin{array}{l}12-36 \\
48-88\end{array}$ & - & $\begin{array}{l}36-48 \\
88-100\end{array}$ & 120 & $\begin{array}{l}0-28 \\
40-79\end{array}$ & - & $\begin{array}{l}28-40 \\
79-91\end{array}$ & 92 \\
\hline $\begin{array}{l}\text { Nalerigu } \\
\text { (HAP11) }\end{array}$ & $\begin{array}{c}\text { Panabako } \\
\text { Gambaga }\end{array}$ & $\begin{array}{l}0-31 \\
55-116\end{array}$ & - & $\begin{array}{l}31-55 \\
116-140\end{array}$ & 155 & $\begin{array}{l}0-28 \\
43-102\end{array}$ & - & $\begin{array}{l}28-43 \\
102-128\end{array}$ & 129 \\
\hline $\begin{array}{r}\text { *Nakpeuk } \\
\text { (HAP12) }\end{array}$ & $\begin{array}{c}\text { Panabako } \\
\text { Gambaga }\end{array}$ & $\mathbf{0}-\mathbf{3}$ & 3-166 & - & 166 & $\mathbf{0}-\mathbf{3}$ & $3-146$ & - & 146 \\
\hline $\begin{array}{l}\text { *Yagbum } \\
\quad(\text { WVB10) }\end{array}$ & $\begin{array}{l}\text { Panabako } \\
\text { Damango }\end{array}$ & $0-35$ & $40-100$ & $35-40$ & 100 & $0-34$ & $40-98$ & $34-40$ & 98 \\
\hline $\begin{array}{c}\text { *Bugya-Pala } \\
\text { (WVB11) }\end{array}$ & Pendjari Oti & $0-7$ & $7-56$ & - & 56 & $0-4$ & $4-53$ & - & 53 \\
\hline Tinguri & Pendjari & $27-36$ & - & $0-28$ & 51 & $27-35$ & - & $0-27$ & 49 \\
\hline (WVB12) & Oti & $45-48$ & & $36-46$ & & $45-48$ & & $35-45$ & \\
\hline $\begin{array}{l}\text { *Galiwei } \\
\text { (WVB13) }\end{array}$ & Obosum Oti & $0-32$ & $32-100$ & - & 100 & $\mathbf{0}-\mathbf{3}$ & 3-97 & - & 97 \\
\hline
\end{tabular}

* Open wells, Italic font closely verified by logging, Bold font discrepancy between driller's and log values

Discrepancy in or improved geological record

The results from gamma and formation resistivity/conductivity $\log$ s were used to provide information on rock lithology as well as on lithology boundaries. This is based on the level or variation pattern in resistivity, conductivity, and gamma radiation values. The borehole logs of Tachecku borehole (Fig. 4), drilled in the Pendjari Oti group, illustrate how the logs add information to the driller's and the geologist's records. As seen in Fig. 4, both the supervising geologist and the driller noted that the uppermost $100 \mathrm{~m}$ of rock penetrated by drilling was homogeneous siltstone. The pattern of the gamma as well as of the conductivity logs, however, show frequent shift between low and high gamma values, indicating frequent occurrence of intercalating sandstone beds in the siltstone. Similarly in Fig. 6, the gamma as well as the formation conductivity log verify the geologist's subdivision of the $120 \mathrm{~m}$ Pendjari Oti sandstone at Zabaraya into two main units, i.e., an uppermost dark gray sandstone underlain by a greenish gray sandstone where the upper sandstone has higher gamma radiation, and higher formation conductivity than the lower one, but with their boundary at $63 \mathrm{~m}$ rather than at the suggested $70 \mathrm{~m}$. The geologist further describes the greenish gray sandstone as more fine-grained from $68 \mathrm{~m}$ depth, which is also verified but only by the formation conductivity log showing a slightly lower conductivity from that depth downwards.

Finally, as presented in Fig. 7 the driller (column 2) as well as the supervising geologist (column 3) noted the $118 \mathrm{~m}$ rock penetrated at Murugu as predominantly sandstone (from Panabako group). However, the logging detected the occurrence of high gamma and high formation conductivity response values within the depths of 31-35, 


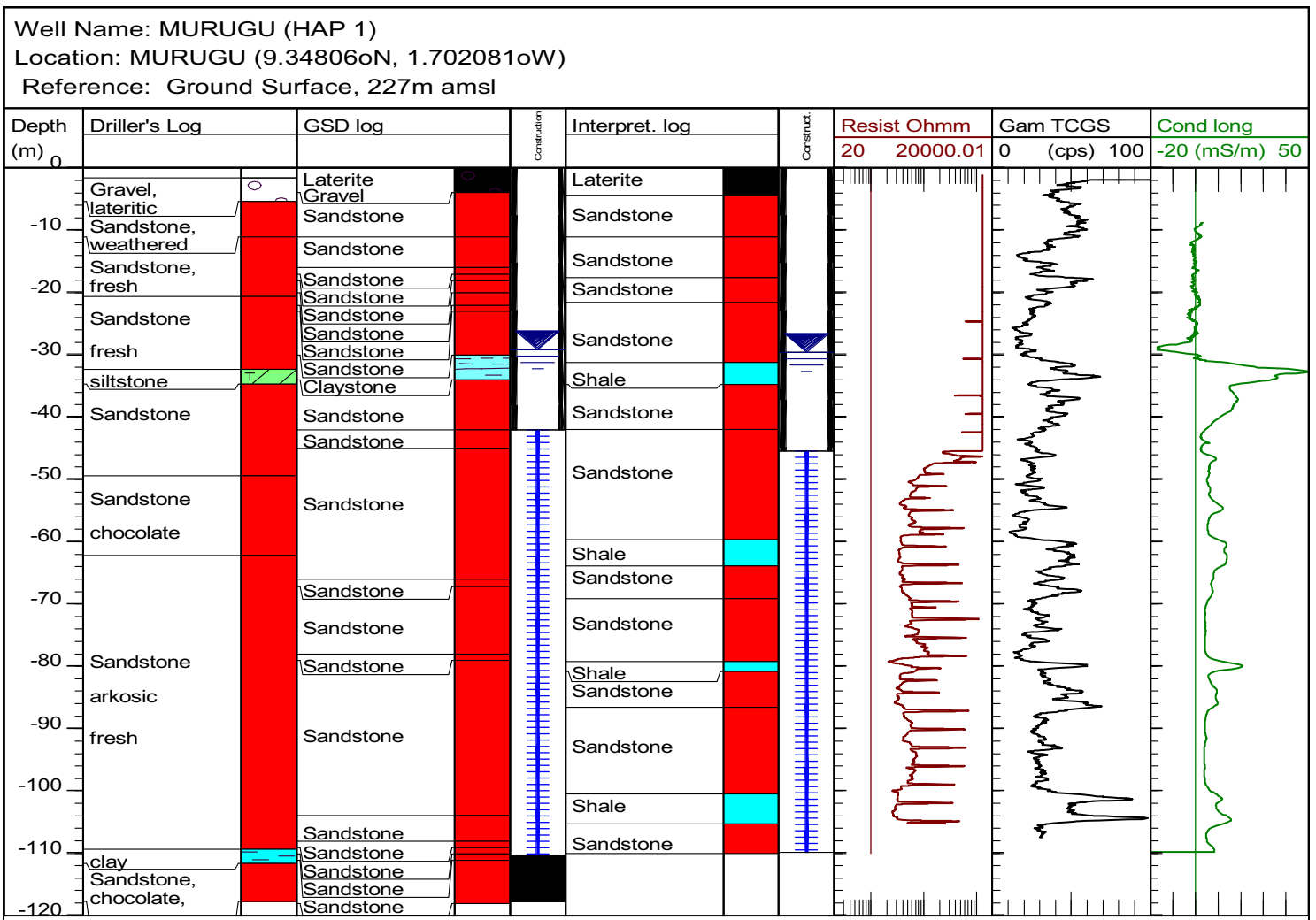

Fig. 7 Logs showing geological verification in borehole at murugu

60-64, 79-86, and 100-106 m, which indicates the presence of interlayering shale or clay beds within the sandstone formation, as described under 'interpreted log' in column 4 (Fig. 7). Apart from the upper clay bed within the depth of $31-35 \mathrm{~m}$, the other clay beds were neither detected by the driller nor by the geologist. Yet geological information seems possible to interpret from the gamma $\log$, because at least the uppermost $100 \mathrm{~m}$ of the sandstone might be subdivided into four sequences each having on average, a downward decreasing gamma radiation and a thickness of, respectively, 30, 30, 20, and $20 \mathrm{~m}$. The conductivity within each of the three lowermost sequences is similarly decreasing downwards, whereas the uppermost sequence is having no conductivity at all because of being above the groundwater table. The generally downward decreasing gamma radiation and formation conductivity of such thick sequences are normally interpreted as downwards coarsening marine sediment (Rider 2000).

\section{Conclusion}

In all the 13 investigated boreholes penetrating into Voltaian rocks, the gamma ray log complemented with either the formation resistivity, or formation conductivity log has added important supplementary information to the geological profiles reported by both the driller and the field geologist. These include detailed lithologic boundaries, homogeneity, bedding intensity and subdivision of rocks into lithological units, but also possible structural downwards fining or downward coarsening, intercalations of sandstone within silt or mudstone or of shale and claystone within sandstone. The formation resistivity tool has furthermore shown its adequacy for controlling the reported screen setting depths that were found seriously erroneous in five of the seven fully constructed boreholes investigated.

The several reported cases of reduced borehole yields after construction might be caused by improper screen setting depths and displaced gravel packing combined with inadequate quality of the gravel pack material, which leads to partial blocking of productive water sections. This sort of problems could be diminished by strengthening the supervision of drilling activities in the field as indicated by this study. Disputes that often arise between drillers and clients in terms of depths drilled and screen settings could be reduced significantly if geophysical borehole logging is conducted prior to borehole completion and design of screen settings. However, the actual completed construction needs afterwards to be controlled by resistivity logging, but not necessarily using sophisticated and expensive equipment. Screen setting control can be done by the drilling supervisor by applying a resistivity meter and simple cable 
tool with conventional electrode probe. Such controls could then provide the basis for economic interventions as e.g., full payment to drilling contractor made on condition that the borehole is constructed in accordance with the contractual technical specification.

Development of the hydrogeological characteristics of the Voltaian rocks is based primarily on linking the observed water bearing capacity of the boreholes to the actual lithology and stratigraphy of the rocks penetrated by the boreholes. Therefore, reliability of the borehole records including the construction details and the geological profile is fundamental. This study raises doubt about the reliability of this information and indicates need for improvement. In addition, diagnosing poor well performance requires a good understanding of the completion actually in place, rather than the one that was planned. Most probably, it is the productivity of many boreholes in the country compromised by poor depth control of screen settings, combined with inadequate gravel pack material. Accordingly, independent drilling supervision should be strengthened and borehole logging at least of a few and randomly selected boreholes could be made as an integral part of all government drilling projects in the country, with the Community Water and Sanitation Agency (CWSA) being responsible to enforce the practice.

Acknowledgments The authors are very much grateful to the Canadian-funded Hydrogeological Assessment Project (CIDA-HAP) of northern Ghana and the DANIDA-funded groundwater monitoring project of the White Volta River basin of Ghana for allowing us to use their borehole logging data on their monitoring boreholes for this paper.

Open Access This article is distributed under the terms of the Creative Commons Attribution License which permits any use, distribution, and reproduction in any medium, provided the original author(s) and the source are credited.

\section{References}

Acheampong SY, Hess JM (2000) Origin of the shallow groundwater system in the southern Voltaian Basin of Ghana: an isotopic approach. J Hydrogeol 233(1-4):37-53

Affaton P (2008) Litho-stratigraphy of the Volta basin and related structural units. In: Kalsbeek F (ed) The Voltaian Basin, Ghana. Workshop and Excursion Report. March 10-17, 2008, Abstract Volume. Geological Survey of Denmark and Greenland (GEUS), Copenhagen, pp 13-17

Agyekum WA, Dapaah-Siakwan S (2007) Report of geo-logging and diver installation of HAP monitoring boreholes. WRI Technical Report to Water Resources Commission, Ghana
Bates DA (1966) Geological Map of Ghana on the scale 1;1000,000, Map of mafic dyke provinces, Bahia

Carney J, Jordan C, Thomas C, McDonnel P (2008): A revised lithostratigraphy and geological map of the Voltaian basin derived from image interpretation and field mapping. In: Kalsbeek F (ed), The Voltaian Basin, Ghana. Workshop and Excursion, March 10-17, 2008, Abstract Volume. Geological Survey of Denmark and Greenland (GEUS),Copenhagen, pp 107-132

Dapaah-Siakwan S, Gyau-Boakye P (2000) Hydrogeologic framework and borehole yields in Ghana. Hydrogeol J 8(4):405-416

Darko PK (2001) Quantitative aspects of hard rock aquifers: Regional evaluation of groundwater resources in Ghana. Summary of $\mathrm{PhD}$ Dissertation, Charles University, Prague

Darko PK, Krasny J (2007) Regional transmissivity distribution and groundwater potential in hard rocks of Ghana. In: Krasny-HrkalBruthans (ed) Groundwater in Fractured Rocks (2003)-Prague, Czech Republic

Freeze RA, Cherry JA (1979) Groundwater. Prentice Hall Inc. Englewood Cliffs, New Jersey

Frempong DG, Kortatsi BK (1994) Some problems associated with the development of groundwater resources in Ghana. In: Suokko T, Soveri J (eds) Future groundwater resources at risk Publ 222. International Association of Hydrological Sciences, Willingford, pp 389-398

Ghana Statistical Service (2005) Ghana 2000 population and housing census report of Ghana. Ghana Statistical Service, Accra-Ghana

Gills HE (1969): A groundwater reconnaissance of the Republic of Ghana, with a description of geohydrologic provinces. US Geological Survey, Water Supply Paper 1757-K Washington, pp 37

Jordan C, Carney J, Thomas C, McDonnel P (2008) Application of remote sensing and field mapping to a revision of the geology of the Volta basin. In Kalsbeek F (ed) The Voltaian Basin Ghana. Workshop and Excursion, March 10-17, 2008. Abstract Volume. Geological Survey of Denmark and Greenland (GEUS), Copenhagen, pp 107-132

Junner NR, Hirst J (1946) The geology and hydrogeology of the Voltaian basin. Gold Coast Geological Survey, Memoir No. 8

Kettelar (2005) Viewlog System for log interpretation. Toronto, Ontario

Keys Scott W (1997) A Practical guide to borehole geophysics in environmental investigations. CRC Press, Inc. Lewis Publishers, London

MacDonald AM, Calow RC, Andrews AJ, Appiah S (1996) Groundwater management in drought prone area of Africa Northern Ghana. Keyworth. British Geological Survey, Nottingham

Martin N, van de Giesen N (2005) Spatial distribution of groundwater use and groundwater potential in the Volta River basin of Ghana and Burkina Faso. IWRA Water Intern 30(2):239-249

Nathan Consortium (1970) 'Framework for River Basin Planning', Ghana Sector Studies, Interview Report for Ministry of Finance and Economic Planning, Accra-Ghana

Rider MH (2000) The Geological Interpretation of Well Logs. 2nd edn, Whittles Publishing, Scotland 